\author{
Metka Skubic \\ Mag. Ana Polona \\ Mivšek \\ Zdravstvena fakulteta \\ Univerze $v$ Ljubljani
}

\section{IZZIVI ZA KAKOVOSTNO IZOBRAŽEVANJE V PRIPRAVI NA POROD IN STARŠEVSTVO}

\section{POVZETEK}

Prispevek prinaša pregled in analizo obstoječe prakse izobraževanja kot dela priprave na porod na primeru šole za bodoče starše v Sloveniji. Raziskava ugotavlja potrebe po spremembah v organizacijskem in vsebinskem smislu. Avtorici najprej predstavita interdisciplinarne vsebine babištva, porodništva in družinske andragogike ter dejavnike, ki vplivajo na učinkovitost izobraževanja za bodoče starše glede na značilnosti različnih modelov izobraževanja.

Avtorici ugotavljata, da je $v$ slovenskem prostoru vzpostavljena tradicija izobraževalnih programov za pripravo na porod in da se programi le počasi prilagajajo spremembam, ki jih lahko zasledimo v tujini, kjer se vse bolj uveljavljajo modeli, ki poudarjajo individualiziran pristop ter kontinuiteto $v$ obravnavi od priprave na starševstvo, med nosečnostjo, porodom in v poporodnem obdobju. V letu 2010 je bila v Sloveniji prvič izvedena pilotna študija Zdrave ženske - zdrave družine prihodnosti, projekt, v katerem je bilo izobraževanje za bodoče starše izvedeno na interdisciplinaren način s strokovnjaki različnih strok ter usmerjeno v potrebe žensk in njihovih partnerjev na prehodu v starševstvo. Gre za prvi poskus novega načina izobraževanja in obravnave za bodoče stař̌e v slovenskem prostoru, ki pa ga obstoječi zdravstveni sistem (̌̌e) ne podpira. Udeleženci so najvišje ocenili organizacijo in izvedbo programa s poudarkom na načinu podajanja snovi oziroma izbiri metode in oblike izobraževanja. Rezultati kažejo, da si udeleženci projekta pri izobraževanju za bodoče starše želijo več poudarka na vsebinah poporodne obravnave, partnerskega odnosa in nasvetov glede dojenja. Posebej izpostavljeni so bili svetovalno delo ter kontinuiteta in individualna obravnava vsakega para.

Ključne besede: rojstvo, starševstvo, šola za starše, izobraževanje.

\section{CHALLENGES FOR QUALITY EDUCATION IN CHILDBIRTH AND PARENTHOOD PREPARATION - ABSTRACT}

The article presents an overview and analysis of current practices in antenatal classes in Slovenia. The findings of the recent study show that organizational changes and changes in the content are needed in this field. Authors firstly present the interdisciplinary issues of midwifery, obstetrics and family andragogy and link them with factors affecting efficiency of parenthood education, according to different models of education.

It is established that Slovenian antenatal education has a rich history; however, recent foreign innovations are being adopted only slowly. Models of care that promote individualized continuous midwifery care during pregnancy, birth and postpartum period are becoming a standard practice abroad. They require a new approach to parenthood preparation.

In order to test the model of continuity of midwifery care in the Slovenian context, a pilot study was carried out in 2010. The project Healthy Women - Healthy Families involved antenatal classes that were run according to contemporary guidelines of best practice. An interdisciplinary approach was adopted to address all the needs of women and their partners in the transition to parenthood. This was the first attempt to innovate the current approach of parentcraft educational programmes in Slovenia. The participants of the project expressed a high level of satisfaction with continuity of midwifery care and counselling opportunities, organization and realization of the programme. They praised the new approach and methods of education introduced in antenatal classes. For the future, they expressed the wish to get more information regarding postnatal adaptation, breast-feeding and the opportunity to speak more freely about the effects a child has on relations between partners. In conclusion the authors present a list of suggested improvements for the Slovenian antenatal classes, based on the relevant literature and the experience gained during the pilot study.

Keywords: birth, parenthood, antenatal classes, education.

UDK: 374.7 


\section{UVOD}

V sodobnem času se mora posameznik nenehno izobraževati za življenje, poklic in različne vloge, ki jih sprejema v življenju. Vse to je posledica velikih sprememb in hitrega tempa, ki nam ne dovoli, da bi na različnih področjih zaostali v védenju in veščinah. Za starševsko in partnersko vlogo se nihče posebej ne pripravlja. Prevzemanje vloge očeta in matere se dogaja $v$ procesih socializacije, tako da se znanja, vrednote in stališča večinoma oblikujejo priložnostno v izvorni družini in okolju, kjer moški in ženska živita. Veliko ljudi je prepričanih, da se za vlogo staršev usposobijo že v mladosti v svojih družinah, toda socializacija v družini v družbi hitrih sprememb ne daje dovolj za prevzemanje starševske vloge. Prav tako vzorec, ki ga doživimo doma, za kakovostno življenje v partnerskem in družinskem življenju ni vedno osrečujoč in primeren. To pomeni, da so lahko znanja in vrednote neustrezni za sodobne odnose. Vse bolj se zavedamo, da samo negovani odnosi prinašajo varnost in pogum, ki ga človek v fluidni družini potrebuje.

Obdobje pričakovanja novega družinskega člana je čas, ki se ne ponovi, je prehod, ki prinese veliko sprememb, in izkušnja, ki naj ne bi puščala grenkih spominov. Za to so v prvi vrsti odgovorni bodoči starši sami, v drugi pa tudi vsi, ki se z njimi na tak ali drugačen način ukvarjajo (babice, zdravniki, izobraževalci, svetovalci).

Priprava na porod in starševstvo oziroma kakor je poimenovana $\mathrm{v}$ večini primerov, »šola za bodoče starše «, je neformalna oblika izobraževanja in je del spleta dejavnosti priprave na porod ter integralni del predporodne babiške obravnave nosečnice in njene družine. Bodoče starše naj bi oborožila $\mathrm{z}$ objektivnimi, najnovejšimi informacijami, ki jim bodo omogočile kompetentne odločitve/izbire o lastni obravnavi med nosečnostjo, porodom in v poporodnem obdobju, zato je nujno, da so zdravstveni strokovnjaki, ki vodijo priprave na porod in starševstvo, ustrezno strokovno usposobljeni na ravni vsebin in na ravni andragoškega procesa (Nolan, 1997: 1202).
Rojevanje je kompleksen pojav, ki ima fizične, psihične, socialne, moralne, ekonomske in druge dimenzije. Vsaka nosečnost, zlasti prva, pa prinese številne spremembe. Par se sooči z vprašanji, ki se nanašajo na samo nosečnost (fiziološke spremembe na telesu in v psihičnem počutju, priporočila o zdravem načinu življenja, telesna dejavnost, spolnost itd.), na porod (potek poroda, možnosti glede porodnega okolja in načina poroda idr.), pa tudi na obdobje po rojstvu otroka (dinamika odnosov v družini po prihodu novega člana, nega otroka, poporodne fiziološke spremembe na telesu in psihi ženske) (Schott in Priest, 2002: 1, 2). Vse močnješi trend med nosečnicami je tudi želja po soodločanju o lastni obravnavi med porodom. Poleg tega študije kažejo na razhajanje med željami in pričakovanji ter zadovoljstvom parov s pripravami na porod in starševstvo (O'Meara, 1993; Schott, 2003; Murphy Tighe, 2010). Vse to kliče po spremembah (Walsh, 2006: 82; Carter, 1997) obporodne obravnave.

Avtorici se v raziskavi sprašujeta, kaj povzroča, da priprave na porod in starševstvo ne zadostijo pričakovanjem udeležencev. V prispevku se osredotočata na metode in oblike izobraževanja odraslih, ugotavljata potrebe po izobraževanju za bodoče starše z vidika partnerskega odnosa in družinskega življenja na prehodu $\mathrm{v}$ starševstvo. V drugem delu besedila je predstavljen projekt Zdrave ženske - zdrave družine prihodnosti, ki je testen program $\mathrm{z}$ individualnim pristopom in kontinuirano babiško obravnavo. Projekt je potekal v sodelovanju med Mestno občino Ljubljana in Zdravstveno fakulteto Ljubljana, Oddelkom za babištvo.

\section{IZOBRAŽEVANIE ZA BODOČE STARŠE, PARTNERSKI ODNOS IN DRUŽINSKO ŽIVLJENJE NA PREHODU V STARŠEVSTVO}

Za izobraževanje staršev se uporabljajo različni termini: izobraževanje za starševstvo, družinsko izobraževanje, svetovalno delo za star- 
še, izobraževanje za družinsko življenje, delo s starši. Tu bi lahko dodali tudi izobraževanje za bodoče starše, zdravstvenovzgojno delo z bodočimi starši in usposabljanje za bodoče starše, kar kaže na različna časovna obdobja, v katerih Priprava na porod
in starševstvo je
neformalna oblika
izobraževanja. so programi nastajali, in tudi na različna teoretična izhodišča pri pripravi programov. Večino spretnosti in informacij, ki jih potrebujemo za starševsko vlogo, pridobimo po neformalni poti. Ličen (1999) ugotavlja, da starši začnejo načrtno iskati znanje šele takrat, ko se srečajo s problemom, ki ga sami ne znajo rešiti. Za izobraževanje in informiranje uporabljajo razne revije in knjige, pogosteje pa se zatekajo po odgovore k prijateljem, znancem in na spletne forume.

Sodelovanje pri starševstvu je zelo pomembno področje sodelovanja dveh odraslih, saj je starševstvo na eni strani vir rasti za moškega in žensko, na drugi strani pa izraz njune zrelosti in sposobnosti za sprejemanje odgovornosti zase in za druge. Kompan Erzar (2003: 111) zapiše, da starševstvo ni nikoli samo ovinek v življenju mladega človeka, samo skrb, naloga in breme, ampak hkrati pretrganje in utrditev medgeneracijskih vezi prek poglobitve odnosa med mladima staršema. Njun sistem dajanja in sprejemanja se razširi na otroka (Ličen, 1997), saj, kot dodaja (Musek, 1995: 134), šele rojstvo otroka pomeni oblikovanje družine $\mathrm{v}$ pravem pomenu. Izobraževanje, povezano z vlogo staršev, vključuje vsebine s področja starševske vloge in s področja partnerske vloge, kar se $\mathrm{v}$ programih priprave na starševstvo uveljavlja šele v zadnjih letih.

\section{PREGLED PRIPRAVE NA POROD IN ROIEVANIE SKOZI ZGODOVINO - RAZVOJ ŠOLE ZA BODOČE STARŠE V SLOVENIJI}

Različna obdobja zgodovine so zaznamovali različne življenjske razmere, različni medseboj- ni vplivi kultur ter gospodarska, socialna in politična dogajanja. Te spremembe so se kazale tudi v življenju družine. Pogled v družino in delitev dela med možem in ženo v preteklosti nam je v veliko pomoč pri razumevanju razvoja očetove in materine vloge ter njunega položaja $\mathrm{v}$ času pripave na porod in poroda samega. $\mathrm{V}$ obdobju pred organiziranim izobraževanjem za starševstvo so si informacije o porodu in starševanju ženske izmenjevale med seboj (Nolan, 1997).

Biološko rojevanje ostaja vedno isto, skozi obdobja pa se spreminja vse drugo, kar spremlja porod. O pripravi na porod kot o organizirani skupinski obliki izobraževanja govorimo šele od 30. let 20. stoletja naprej in je sprva potekalo individualno na domu nosečnice, pozneje, ko se je porod preselil v zdravstvene ustanove, pa se je tja preselila tudi priprava na ta dogodek. Leta 1933 je angleški porodničar dr. Grantly Dick Read začel propagirati t. i. naravni porod. Po njegovem mnenju je porod naravno dogajanje, poudarjal je čustveno oporo, dotik in bodrenje ter se zavzemal za aktivnejšo vlogo očeta, čeprav njegov koncept ne govori o porodnem trenerju (Milošević in Prica, 1967). Leta 1950 izobraževanje nosečnic prevzamejo babice in poteka v sklopu dejavnosti porodnišnic in bolnišnic (Nolan, 1994; Zwelling, 1996). Sprva se izobraževanje osredotoča predvsem na fizične vidike poroda in poporodnega obdobja, po ugotovitvah porodničarjev (predvsem Velvovskega, Nikolajeva, Reada in Lamaza), da na porodno bolečino zelo vpliva tudi psihična pripravljenost ženske na porod, pa se programi dopolnijo še z vsebinami s psihološkega vidika. Dick-Read je menil, da porod, ki poteka po naravnih zakonitostih, ni nikoli (pre)boleč oziroma nevzdržen za žensko (Dick-Read, 1957, cit. po Leap in Anderson, 2008), ki je, ob primerni podpori babice, zmožna mobilizirati svoje notranje moči in energijo popadkov uporabiti v svojo korist za napredovanje poroda. Oblikoval je metodo priprave na porod, ki je pretrgala vzorec strah - napetost - bolečina ter preusmerila pozornost ženske, obenem pa se je 
Prve informacije o vzgoji in izobraževanju je iz Anglije v Slovenijo, na Ginekološko kliniko v Ljubljani, prinesel prof. dr. D. Vilfan. Na Ginekološki kliniki v Ljubljani je pripravo na porod začela izvajati prim. dr. Lea Ozimič - Trampuž leta 1955. Tečaj priprave na porod je najprej potekal po Readovi metodi pod imenom psihoprofilaktična priprava na porod, kasneje pa se je bolj uveljavila ruska psihoprofilaktična metoda. Zaradi zanimanja nosečnic za pravilno nego in prehrano dojenčka, za poporodno obdobje in oblike kontracepcije po porodu, za spremembe, ki jih nosečnost in rojstvo otroka vnašata v partnerski odnos, so leta 1968 tečaj preimenovali v materinsko šolo (Oberstar, 2003). Poleg tečaja predporodne priprave je potekal še tečaj za nosečnice v zgodnji nosečnosti in telovadba od tretjega meseca nosečnosti naprej. Ob tečajih je potekalo še individualno delo z nosečnicami in izvajanje dekompresij po Heynsu. Ko so se poroda začeli udeleževati tudi partnerji in so nasploh očetje dobili aktivnejšo vlogo pri negi otroka, se je izkazalo, da tudi ti potrebujejo pripravo za očetovanje, zato se je leta 1991 tečaj spremenil in preimenoval v šolo za starše (Oberstar, 2011: 152). Izobraževalni program nudi skupna predavanja za oba starša, pa tudi ločeno pripravo za očete.

ženska, na podlagi informacij o dogajanju med porodom, otresla strahu pred neznanim, kar je pripomoglo k nadaljnji sprostitvi. Na podobnih temeljih so slonele tudi druge teorije: npr. teorija ruskih porodničarjev in Lamazova teorija. Tečaji, razviti na dognanjih omenjenih porodničarjev (Dick-Read, 1944; Lamaze, 1958), se v praksi z različnimi modifikacijami uporabljajo še dandanes (Jaddoe, 2009). Kljub temu jasne definicije in ciljev priprave na porod in starševstvo ni, čeprav jo po drugi strani izvajalci in uporabniki opredeljujejo dokaj enotno - pridobivanje znanj, samozavesti za porod ter krepitev kompetentnosti za starševstvo (Schott in Priest, 2002).

Pravna podlaga za delovanje šole za starše v Sloveniji je Navodilo za izvajanje preventivnega zdravstvenega varstva na primarni ravni (Uradni list RS, št. 19/98, 47/98, 26/00, 67/01, 33/02, 37/03, 117/04, 31/05, 83/07, 22/09), katerega del je tudi Predporodna zdravstvena vzgoja - šola za starše. Predpis določa vsebine, izvajalce in smernice za delo (točka 1.3.4.), po katerih naj bi šole za starše delovale. Določila so dokaj natančna glede vsebin programa, vendar Skubic v svoji raziskavi (2007) ugotavlja pomanjkljivosti glede vsebin, ki obravnavajo odnos med partnerjema, vlogo očeta, odnos $\mathrm{v}$ prehodu iz diade $\mathrm{v}$ triado in pomen navezovanja stika po porodu. Očitno je, da je predpis, ki ga je izdal minister za zdravje, usmerjen predvsem v zdravstvene vidike ozi- roma vidike fiziologije poroda. Skubic dodaja, da bi bilo v prihodnosti priporočljivo razširiti predpisane toge okvire in predlagati bolj fleksibilne možnosti glede vsebin, ki bi jih lahko načrtovalci in izvajalci programov izbirali glede na potrebe udeležencev.

\section{METODE IN OBLIKE IZOBRAŽE- VANJA ODRASLIH V PROGRA- MIH PRIPRAVE NA POROD}

Vzgojno-izobraževalna praksa zahteva uporabo tistih metod izobraževanja, ki odraslemu človeku omogočajo, da pridejo do izraza njegove izkušnje, znanje, mišljenje in aktivnost. V šoli za bodoče starše je to zelo pomembno, saj je njen namen bodočim staršem približati nova znanja za novo pot, tako da bodo v obdobju, ki prihaja z rojstvom otroka, znanja iz teorije znali prenašati v prakso in bo to spodbudilo refleksijo o lastnem vedenju in načinih oblikovanja starševske vloge. V vzgojno-izobraževalnih programih priprave na porod se najpogosteje uporabljajo naslednje metode: predavanje, demonstracija, diskusija, delo s pisnimi viri, delavnice in vse pogosteje tudi e-učenje, npr. prek spletnih forumov in drugih omrežij. V naši raziskavi smo ugotovili, da je v programih priprave na porod najpogosteje uporabljena metoda še vedno predavanje (prim. Skubic, 2007). Poudarek je na podajanju sistematično urejenih podatkov in manj na razvijanju komu- 
nikacije. Pri izobraževanju odraslih uporabljamo metodo predavanja $\mathrm{v}$ povezavi $\mathrm{z}$ drugimi metodami. Navadno je predavanju namenjen uvodni del, ki mu sledi učenje z metodo primera, diskusije, simulacije.

Demonstracija je druga najpogostejša metoda v vzgojno-izobraževalnih programih priprave na porod. Bistvo demonstracije je v prikazovanju predmetov, pojavov, odnosov med ljudmi, da bi se udeleženci kar najbolje soočili z novimi situacijami in $\mathrm{z}$ neposrednim opazovanjem prišli do popolnejših predstav, pojmov, zaključkov, generalizacije. Metoda je zasnovana na kompleksni percepciji in nazornosti, ki omogočata popolnejše in trajnejše znanje. Poskrbeti je treba, da se udeleženci dejavno vključijo v opazovanje predmeta, giba ali opravila, ki se demonstrira. V šolah za bodoče starše se metoda demonstracije uporablja predvsem za to, da bodočim staršem pokažejo in jih naučijo, kako ravnati z novorojenčkom in dojenčkom, previjanja, kopanja in oblačenja. Priporočljivo bi bilo, da bi metodo uporabljali tudi za prikaz porodnih položajev, priporočljivih položajev spanja in položajev pri predihavanju popadkov. Uporablja se tudi demonstracija predmetov (model ženske medenice, porodna miza, pripomočki za nego dojenčka itd.), prikaz slik in diapozitivov.

Zelo pogosto se uporablja metoda diskusije. Odrasli z diskusijo preverjajo veljavnost vsebin, o katerih se učijo, in tako poglabljajo svoja znanja. Diskusija je metoda, kjer pridejo do izraza znanje in izkušnje udeležencev. Slednje so zelo pomembne predvsem v skupinah s pari, ki že imajo otroka. Tako se z znanjem in izkušnjami bogatijo vsi udeleženci. Vsak pove, kar ve, in tako drug drugega dopolnjujejo. Izvajalec šole za starše diskusijo vodi in usmerja $\mathrm{k}$ izobraževalnemu cilju, da poslušalci osvojijo predvidena znanja. Za uspešno razpravo pa je treba izpolniti nekatere pogoje: primerni fizični pogoji (prostor, oprema, glasnost), primerna socialna klima (zaupanje) in sočuten vodja, ki je sposoben »prebiti led«(Krajnc, 1979).
Tudi igranje vlog daje možnosti za vajo in učenje komunikacije ter za ocenjevanje in reševanje problemov. Med pripravo na porod se kot vaja/simulacija izvaja »potek poroda«, da bi se pari pripravili na popadke in porod. Metoda igranja vlog je $\mathrm{v}$ programih priprave na porod opredeljena kot način, s katerim se posamezniki spoznavajo, opazujejo svoje vedenje in se učijo vlog, ki jih bodo imeli ob porodu.

Cilji igranja vlog in simulacije poroda:

- približno začutiti, kako naj bi se počutili med porodom;

- omogočiti parterju, da vadi spretnosti, ki se jih je naučil na tečaju;

- izboljšati in pospešiti neverbalno komunikacijo med partnerjem in porodnico;

- sodelovati $\mathrm{v}$ porodni situaciji in nuditi pomoč pri poteku poroda.

Pred uporabo te metode je nujno, da učitelj vse simulirane situacije tehnično dobro obvlada. Vsaka scena lahko vključuje številne stresne situacije in stiske, s katerimi se lahko sreča par v porodni sobi, npr. nadzorovanje dihanja, masaža, nadzorovanje popadkov, interakcija z osebjem. Dejanski dialog med sodelujočimi je spontan. Navadno dva igrata, drugi opazujejo, učitelj pa zavzame mesto opazovalca ali mesto strokovnega delavca. Metoda igre vlog se uporablja po nekaj srečanjih, ko se udeleženci že naučijo tehnik dihanja in sproščanja in se bolj vživijo v vlogo. Koncu vsakega prizora sledi diskusija, v kateri sodelujejo vsi udeleženci tečaja; njen namen je pregled dogajanja. Igranje vlog pare zabava in hkrati motivira, da kaj podobnega poskusijo tudi doma (Brookfield, 1986).

V šoli za starše bi bilo poleg metode igranja vlog primerno uporabljati tudi metodo prime$r a$, ki je učinkovita zato, ker sledi dialektičnemu mišljenju odraslih, saj imajo različni dogodki in zapleti vedno različne možne rešitve. Metoda primera je navadno didaktično urejena oblika resničnega dogodka, kjer je primer izbran tako, da je blizu življenjskim situacijam udeležencev, in sicer zato, da lahko svoje znanje in izkušnje uporabljajo za analizo. Poveže- 
mo jo lahko z metodo simulacije, pri slednji problema ne analiziramo le na verbalni ravni, ampak ga tudi doživljamo.

Zanimiva nova možnost za izobraževanje odraslih v šoli za starše so tudi različne metode, ki so se razvile s pojavom informacijsko-komunikacijske tehnologije. Danes lahko najdemo mnoge spletne povezave, ki jih s pridom uporabljajo tudi bodoči starši. Pri teh je pomembno, da imajo dobre in strokovno usposobljene moderatorje.

Vedno pogostejša oblika je svetovanje. To je prilagojeno posameznemu paru in specifičnim problemom, s katerimi se srečujejo posamezniki. Oblike dela, ki se v šolah za bodoče starše najpogosteje uporabljajo, so tečaji in delavnice.

Izobraževanje odraslih, ki se pripravljajo na vlogo starša, naj bi sledilo načelom aktivnega učenja, ki upošteva že pridobljena znanja in jih nadgrajuje, udeležence animira ter jih opolnomoči (Schott in Priest, 2002: 85). Kar se ljudje naučijo na ta način, si dlje zapomnijo (Bligh, 1998). Delo v majhnih skupinah, kjer se pari »izobražujejo« skozi usmerjan pogovor, je pri pripravi na porod in starševstvo v skladu z načeli andragogike (Knowles, 1975, 1978, cit. po Leap, 2010: 30) in se kaže kot učinkovito. Spodbuja neodvisnost in iskanje lastnih rešitev, spoštuje pretekle življenjske izkušnje udeležencev, gradi na njihovi notranji motivaciji za učenje, uporablja problemsko učenje ${ }^{1}$ ter poudarja partnerski odnos učitelja in učenca.

\section{HUMANIZACIJA PORODA IN OBPORODNE OBRAVNAVE V SLOVENIJI TER POMEN KONTINUIRANE OBRAVNAVE ŽENSK IN DRUŽIN}

Pred 200 leti je bil porod humaniziran, kar pomeni, da so porodnicam pomagale babice, ki so ženske postavljale $\mathrm{v}$ središče in so spošto- vale fiziologijo porodnega procesa. S koncem druge svetovne vojne se je začela doba tehnologije. Spremenil se je tudi pogled na porod, ki se je preselil v porodnišnice, kjer so obporodno skrb prevzeli zdravniki, ki s številnimi aparaturami, zdravili ter rutinskimi posegi nadzirajo in usmerjajo porodni proces. Babica je v medikaliziranem okolju porodničarjeva asistentka in ne več zagovornica ženske (Wagner, 2007: 17). V 80. in 90. letih 20. stoletja smo bili priče odzivom na medikalizirani porod in začetkom premikov $\mathrm{k}$ bolj humaniziranemu porodu. Ženska spet postane središče poroda in prevzame nadzor nad porodnim dogajanjem. Obporodne storitve temeljijo na preverjenih znanstvenih podatkih (Wagner, 2007). V tem konceptu se porod vidi kot fiziološko obdobje, ki ne potrebuje zdravljenja, temveč le usmerjanje, svetovanje, podporo, kar lahko zagotovijo babice na primarni ravni zdravstvenega varstva. Ti premiki se kažejo tudi v programih za pripravo na porod (prim. Drglin, 2003 in Drglin, 2007) in pri vpeljevanju posebnih porodnih spremljevalk, kot so doule.

Tudi slovenske ženske vse bolj jasno izražajo željo po spremembah obporodne obravnave (prim. Skubic, 2007). Koncepti izbire, nadzora in sodelovanja so ženskam zelo pomembni oziroma so ključni za njihovo zadovoljstvo (Richards, 1982). Posledično se spreminjajo tudi razmerja moči med zdravstvenimi delavci in uporabnicami storitev. V veljavo vse bolj stopajo pojmi, kot so kakovost ponudbe, pravice potrošnika in s tem možnost svobodnega odločanja o storitvah (Mason, 1995). Ženske, vse bolj dejavne uporabnice, želijo objektivne in znanstveno dokazane informacije, ki jih v odnosu do zdravstvenih strokovnjakov postavljajo v enakovreden položaj. Ne le, da se spreminja pomen priprave na starševstvo in raste vrednost najnovejših znanstveno dokazanih informacij, spreminja se celotna slika obporodnega zdravstvenega varstva. V skladu z opisanimi novimi trendi se ustvarjajo nova pričakovanja in zahteve za babice, kar spreminja tudi 
babiški poklic - babice iščejo ravnotežje med zadovoljevanjem potrebe po fizični varnosti in psihosocialnimi željami žensk (Kitzinger, 1988). Nova situacija od njih zahteva tudi nova znanja in spremembe $\mathrm{v}$ odnosu do žensk. Usta-

Kontinuirana babiška obravnava zagotavlja ženskam fiziološke in psihološke koristi. ljeni pristopi ne zadoščajo več, zato razvijajo nove modele, kot ugotavljajo različne raziskave (Flint in Poulengris, 1986; Twaddle in drugi, 1993; McGinley in drugi, 1995; Turnbull in drugi, 1996; DeVries in drugi, 2001; Davis-Floyd, 2009). Vse bolj se uveljavljajo modeli, ki poudarjajo individualiziran pristop in kontinuiteto v obravnavi: od priprave na starševstvo, med nosečnostjo, porodom in $\mathrm{v}$ poporodnem obdobju. Na to kaže tudi pojav poimenovanja celotnega izobraževanja kot obporodno izobraževanje ali izobraževanje $\mathrm{v}$ obporodnem obdobju, ki zajema izobraževanje pred porodom, oporo med porodom in izobraževanje ter obravnavo po porodu.

Literatura loči med izrazoma kontinuiteta obravnave (angl. continuity of care) in kontinuiteta izvajalca (angl. continuity of carer) (Walsh, 2008). Kontinuiteto obravnave bi lahko opisali kot enotnost prepričanj, usmeritev in vrednot različnih zdravstvenih strokovnjakov, ki žensko obravnavajo (Waldenström in drugi, 2000), kar prepreči nasprotujoče si nasvete in navodila (Green in Murray, 2000, citirano po Zakšek in Mivšek, 2009). V nasprotju s tem pomeni kontinuiteta izvajalca stalno navzočnost ene in iste osebe, ki obravnava žensko od obdobja načrtovanja otroka pa vse do prvega poporodnega leta. Bistveno več prednosti za žensko prinaša kontinuiteta izvajalca obravnave (Proctor, 1998; Williamson in Thomson, 1996). Kontinuiteta babiške obravnave se ženskam oziroma parom lahko zagotovi skozi različne modele; t. i. caseload midwifery, team midwifery in midwifery-led care, pri čemer pa le prva dva zagotavljata tudi kontinuiteto izvajalca (Homer in drugi, 2008;
Walsh, 2008), tretji pa pomeni enotno filozofijo skrbi vseh izvajalcev, ki žensko obravnavajo. Do teh modelov se pozitivno opredeljujejo tudi strokovne organizacije po svetu (Australian College of Midwives, 2007; WHO, 2010; EMA, 2009). Pomemben element kakovostne kontinuirane babiške obravnave je načelo one to one (ena babica za eno žensko; t. i. izbrana babica), ki zagotavlja, da so pari obravnavani individualno, glede na potrebe. Tak način obravnave bi zato moral postati ustaljena praksa v babištvu (Haines in Kimber, 2008), saj študije dokazujejo izjemno pozitivne učinke (Bick, 2003; MacArthur in drugi, 2002). Kontinuiran stik je bistven za zaupljiv odnos med babico in žensko (Lundgren in Berg, 2007), kar ženski omogoča, da izrazi svoja pričakovanja in strahove $\mathrm{v}$ povezavi z nosečnostjo, porodom, poporodnim obdobjem in prevzemanjem starševske vloge (Thorpe in Anderson, 2006). Kontinuirana babiška obravnava zagotavlja ženskam fiziološke in psihološke koristi (Rosen, 2004; Marks in drugi, 2003; Hodnett in drugi, 2007), povečuje njihovo zadovoljstvo (Hodnett in drugi, 2007; SOGC, 1995; Callister, 1993) ter obenem znižuje stroške oskrbe (Hunter, 2002). Dokazano je, da lahko babice s kontinuirano obravnavo delujejo pozitivno, kar posledično vpliva na počutje ženske, njeno dojemanje sebe ter njen odnos do novorojenega otroka (Oakley, 1992). Bistvena razlika kontinuirane babiške obravnave $\mathrm{v}$ primerjavi z običajno je, da žensko iz pasivnega objekta spreminja $\mathrm{v}$ aktivno udeleženko $\mathrm{v}$ procesu obravnave (Gale in drugi, 2001; Williamson in Thomson, 1996; Lundgren in Berg, 2007; Hunter, 2002; Bluff in Holloway, 1994; Hodnett in drugi, 2007), medtem ko pomanjkanje kontinuitete vodi $\mathrm{v}$ depersonalizacijo obravnave.

Glede na trenutno fragmentirano obravnavo slovenskih nosečnic, porodnic in otročnic kontinuirana obravnava ni mogoča. V Sloveniji namreč v nosečnosti, med porodom in v poporodnem obdobju, če slednji potekajo normalno, žensko obravnava najmanj pet do 
sedem različnih zdravstvenih strokovnjakov. O kontinuiteti obravnave torej ni mogoče govoriti (Skočir, 2004).

V letu 2010 je bil poskusno izveden program kontinuirane babiške obravnave v okviru projekta z naslovom Zdrave ženske - zdrave družine prihodnosti, ki je potekal v sodelovanju med Mestno občino Ljubljana in Zdravstveno fakulteto Ljubljana, Oddelkom za babištvo. Eden glavnih namenov projekta je bil parom med pripravo na starševstvo predstaviti najnovejše objektivne informacije na načine, ki temeljijo na načelih andragoškega izobraževanja ter sodobnih aktivnih pristopih k učenju.

\section{PILOTNA ŠTUDIJA ZDRAVE ŽENSKE - ZDRAVE DRUŽINE PRIHODNOSTI}

Temeljni namen projekta je bil ugotoviti zadovoljstvo bodočih staršev $\mathrm{z}$ individualnim pristopom in kontinuirano babiško obravnavo. Projekt je obsegal vsebine priprave na porod in starševstvo, spremljanje žensk in njene družine med nosečnostjo, porodom in $\mathrm{v}$ poporodnem obdobju, vključenih pa je bilo 12 udeleženk (in njihovih partnerjev), ki so zaradi različnih razlogov (slabe predhodne porodne izkušnje, strah pred porodom itd.) želele individualno kontinuirano obravnavo. Za čim večjo kakovost priprav na porod in starševstvo se svetuje, da število udeležencev ne presega 12 parov (torej 24 oseb) (Schott in Priest, 2002: 191).

Program je obsegal tri stopnje: pred-, ob- in poporodno obravnavo. V nosečnosti se je izvajala priprava na porod in starševstvo v obliki šole za bodoče starše, poleg tega so bile vse nosečnice deležne tudi individualne obravnave (svetovanje). Na željo jim je bilo zagotovljeno spremstvo ob porodu. Redne individualne obravnave so sledile tudi v poporodnem obdobju. Med izvajanjem projekta je bilo uvedeno 24-urno dežurstvo na mobilnem telefonu, ki je uporabnicam omogočalo takojšen neposreden stik z izvajalci projekta $\mathrm{v}$ primeru zapletov, vprašanj ali začetka poroda. Uporabnice so ob vstopu v projekt podpisale izjavo o zavestni privolitvi v sodelovanje $\mathrm{v}$ programu ter izpolnile vstopni anonimni vprašalnik, ob koncu pa so izpolnile evalvacijiski vprašalnik. Delo so evalvirali tudi izvajalci, in sicer v obliki rednih sestankov in supervizijskih srečanj (telekonference) s priznano profesorico babištva iz tujine. Program je bil hkrati tudi učni proces za študente babištva višjih letnikov, ki so se vanj aktivno vključevali pod mentorstvom izvajalcev projekta (Stanek Zidarič in drugi, 2011).

\section{PRIPRAVA NA POROD IN STARŠEVSTVO TER SPREMLJANJE NOSEČNOSTI}

V obdobju dveh tednov je bilo organiziranih pet tematskih srečanj na Zdravstveni fakulteti, kar sledi ugotovitvam (Schott in Priest, 2002: 192), da podajanje vsebine po tematikah in $\mathrm{z}$ vmesnimi prekinitvami (več ur ali celo dni) omogoča refleksijo in preprečuje, da bi udeleženci pridobili preveč informacij naenkrat in jih tako ne bi mogli predelati. Vsako srečanje je trajalo po dve šolski uri $\mathrm{z}$ vmesnim odmorom. $\mathrm{K}$ pripravi na porod in starševstvo so bili povabljeni tudi partnerji. Metode dela so bile predavanje, demonstracija in praktična delavnica, ob koncu vsakega srečanja pa je sledila tudi diskusija. Vsebine so temeljile na dokazih iz najnovejših raziskav in so obsegale naslednja področja:

- zdrav način življenja in nosečnost, zdravstveno in socialno varstvo med nosečnostjo,

- psihofizična priprava na porod, potek poroda, bivanje v porodnišnici,

- prihod novorojenčka v družino, partnerski odnos in vzpostavitev stika $\mathrm{z}$ novorojenčkom ter nega novorojenčka,

- poporodno obdobje, poporodno socialno varstvo,

- dojenje in prehrana novorojenčka.

Za bodoče starše je bila pripravljena didaktična brošura s povzetki predavanj, ki so jih lah- 
ko dopolnjevali z lastnimi opombami, zapiski, vprašanji in komentarji. Ob koncu projekta je bila izvedena evalvacija slušateljev (anonimni anketni vprašalnik), samoevalvacija oziroma refleksija (Zakšek in drugi, 2011) ter evalvacija kolegov (na vsakem srečanju je bil navzoč še kateri od članov projektne skupine, ki je lahko izvajalcu ponudil povratne informacije, t. i. peer review), kot to priporoča literatura (Schott in Priest, 2002: 24, 235-243).

Bodočim staršem je bilo med nosečnostjo omogočeno tudi individualno svetovanje. Ker so bile vse nosečnice vključene tudi v obstoječo shemo antenatalnega zdravstvenega varstva, so se srečanja na preglede $\mathrm{v}$ fizičnem smislu osredotočala le na njihovo željo. Anamnestični in drugi podatki so se vodili v Dnevniku vodenja nosečnosti, poroda in poporodnega obdobja, ki je bil za potrebe projekta razvit po tujih modelih.

\section{POROD IN POPORODNO OBDOBJE}

Vse udeleženke projekta so želele navzočnost izbrane babice med porodom. Glede na to, da večina slovenskih porodnišnic omejuje število spremljevalcev ob porodu na enega (navadno je to bodoči oče), je bila na vodstvo porodnišnic, ki so si jih pari izbrali kot kraj poroda, naslovljena prošnja za možnost drugega spremljevalca ob porodu. $Z$ njihovo privolitvijo so se izvajalci projekta parom pridružili kot sekundarni spremljevalci. Izbrana babica je žensko na njeno željo obiskala že v porodnišnici in/ali kasneje na domu. Nudila ji je informacije ter pomoč glede dojenja, samooskrbe, nege otroka itd. Vsem družinam je bila ponujena tudi možnost opazovanja novorojenčkov (Newborn Behavioural Observation Session), ki ga na podlagi izobraževanja $\mathrm{v}$ tujini in pridobljenega certifikata izvajajo izvajalci projekta.

Zaključek projekta je bil v obliki evalvacijskega skupinskega srečanja po porodu za vse udeležence projekta skupaj z dojenčki, kjer je bila izražena želja po skupinskih srečanjih tudi po porodu.

Prednost projekta je, da so izvajalci program sestavili v medsebojnem sodelovanju, se uskladili o vsebinah in organizaciji izvedbe ter si tudi med projektom izmenjevali informacije. Poudarek je bil na interdisciplinarnem pristopu ter kontinuirani obravnavi posameznika in para. S specialnimi znanji so si bili izvajalci v medsebojno pomoč pri reševanju različnih stisk in težav žensk in njihovih družin (Zakšek in drugi, 2011). Če pripravo na porod in starševstvo izvaja več strokovnjakov, je nujno potrebno, da pripravijo program skupaj, se skupaj predstavijo na prvem srečanju, redno komunicirajo o napredku ter skupno evalvirajo uspešnost programa - tako $\mathrm{v}$ organizacijskem smislu kot tudi izvedbeno in vsebinsko (Schott in Priest, 2002: 226, 227). Čeprav se njihovi stili poučevanja razlikujejo, je nujno, da imajo enake cilje in enako filozofijo (Schott in Priest, 2002: 188), npr. strinjanje o tem, da bodo spodbujali informirano odločitev (angl. informed consent), sledili načelom poučevanja odraslih in udeležencem omogočali diskusijo.

\section{ANALIZA STANJA NA PODROČJU DELOVANIA ŠOL ZA BODOČE STARŠE V SLOVENIJI IN EVALVACIJA PROJEKTA ZDRAVE ŽENSKE - ZDRAVE DRUŽINE PRIHODNOSTI}

Izhodišče za pripravo programa ter izvedbo pilotne študije in projekta Zdrave ženske - zdrave družine prihodnosti so bili podatki Inštituta za varovanje zdravja (IVZ), lastna opazovanja pri delu v praksi, intervjuji uporabnic šole za starše ter pregled tujih raziskav in ugotovitev. $\mathrm{Na}$ IVZ so pripravili raziskavo, v kateri so ocenili kakovost šol za starše, ki delujejo po vsej Sloveniji. Kot povzema Skubic (2007), je v raziskavi sodelovalo 46 ustanov. Rezultati študije kažejo veliko neenotnost $\mathrm{v}$ izvedbi tečajev. Predavanja so omejena na eno sreča- 
nje ali pa razdeljena $\mathrm{v}$ sklope (od pet do devet predavanj). Število udeležencev je od pet do 60. Priprave se razlikujejo tudi glede trajanja (šest do 36 ur), vsebin ter izvajalcev (od enega do sedem različnih profilov). Od 46 šol za bodoče starše jih program redno evalvira le 33 v obliki ankete na koncu tečaja. Več kot polovica izvajalcev po Sloveniji (56,5 odstotka) meni, da šole za bodoče starše potrebujejo spremembe, predvsem $\mathrm{v}$ smislu poenotenja minimalnih kriterijev.

Tudi uporabnice želijo spremembe, kot navaja Skubic (2007) in na podlagi analize šole za bodoče starše na Ginekološki kliniki v Ljubljani kot primeru dobre prakse ugotavlja, da izobraževanje še vedno poteka na klasičen (ex chatedra) način. Diskusija je otežena zaradi velikosti skupin (do 60), vsebinsko pa se program osredotoča predvsem na nosečnost in porod. Evalvacija je skromna (na koncu tečaja uporabniki izpolnijo anketni vprašalnik) in ni redna. Uporabnice izražajo nezadovoljstvo predvsem glede številčnosti skupin, neprimernih prostorskih razmer, pomanjkanja znanja izvajalcev o andragoških pristopih in izbiri metod dela.

$\mathrm{Na}$ podlagi dobljenih rezultatov je smiselno razmišljati o smeri snovanja novega enotnega in izpopolnjenega programa za izobraževanje bodočih staršev.

Dodatno potrditev, da so novejši pristopi učinkoviti in dobrodošli, nam dajejo tudi podatki in ugotovitve, ki jih razberemo iz evalvacije projekta Zdrave ženske - zdrave družine prihodnosti. Evalvacija je vključevala evalvacijski vprašalnik, ki so ga udeleženke programa izpolnile po končanem izobraževanju. Program je evalviralo sedem (od skupno 12) udeleženk. Vprašalnik je vseboval pet vprašanj oziroma postavk: (1) Koliko pridobljenega znanja boste lahko uporabili?, (2) Kaj bi želeli pohvaliti?, (3) Ali sta tema in način dela $\mathrm{v}$ programu, v primerjavi z drugimi oblikami usposabljanja, ki ste se jih udeležili, pomembna za vaš osebni razvoj?, (4) Kakšni so vaši predlogi in na katerih področjih bi želeli več poudarka?, (5) Kakšen način podajanja vsebin vam je najbolj ustrezal?

V okviru evalvacije programa Zdrave ženske - zdrave družine prihodnosti smo prišli do naslednjih ugotovitev:

Tabela 1: Analiza vprašanj

\begin{tabular}{|l|c|c|c|}
\cline { 2 - 4 } \multicolumn{1}{c|}{} & $\begin{array}{l}\text { Ocena } \\
\text { organizacije }\end{array}$ & $\begin{array}{l}\text { Koliko pridoblienih } \\
\text { znanj boste lahko } \\
\text { uporabili? }\end{array}$ & $\begin{array}{l}\text { Ali sta tema in način dela } \\
\text { v programu pomembna za } \\
\text { vaš osebni razvoj? }\end{array}$ \\
\hline $\mathrm{N}$ & 7 & 7 & 7 \\
\hline Mean & 5,00 & 4,14 & 4,71 \\
\hline Median & 5,00 & 4,00 & 5,00 \\
\hline Modus & 5 & 4 & 4 \\
\hline $\begin{array}{l}\text { Standardni } \\
\text { odklon }\end{array}$ &, 000 &, 690 &, 378 \\
\hline Varianca &, 000 &, 476 &, 243 \\
\hline Minimum & 5 & 3 & 4 \\
\hline Maximum & 5 & 5 & 5 \\
\hline
\end{tabular}

- Organizacijo izvedbe programa so vse udeleženke ocenile $\mathrm{z}$ najvišjo možno oceno, $\mathrm{tj}$. odlično 5 (glej Tabelo 1).

- Največ udeleženk $(\mathrm{N}=4)$ je navedlo, da bi posebej pohvalile metodo dela, kot način podajanja vsebin pa jim je najbolj ustrezala individualna oblika dela, ki je temeljila na svetovanju $(\mathrm{N}=5)$.

- Udeleženke so s skupno povprečno oceno M = 4,14 ocenile, da bodo lahko uporabile zelo veliko pridobljenega znanja.

- Temo in način dela $\mathrm{v}$ programu so ocenile kot zelo pomembna elementa za svoj osebni razvoj $(\mathrm{M}=4,71)$.

- Za v prihodnje so izrazile željo, da bi bilo še več poudarka na področjih poporodne obravnave, odnosa med partnerjema po porodu, dojenja in dihalnih vaj.

- Pohvalile so svetovalno vlogo babice in $\mathrm{v}$ okviru programa poudarile vrednost njenega spremljanja vsake posameznice posebej skozi različna obdobja nosečnosti do poroda. Po analizi literature in izbranih programov lahko sklenemo, da se tradicija priprave na po- 
rod tudi v našem prostoru dopolnjuje $\mathrm{z}$ novimi spoznanji o vsebinah in načinih izobraževanja. Različne ugotovitve kažejo, da bi v sodobnem času potrebovali zasnovo novega programa, ki bi slonel na dejavnejših metodah izobraževanja in bi prinašal tudi nekatere nove vsebine, zato bi bilo dobro programe pripraviti interdisciplinarno. Organizatorji bi lahko povabili k sodelovanju strokovnjake $\mathrm{z}$ različnih področij in upoštevali modele, ki so se razvili in uveljavili v tujini. Slednjih ni mogoče neposredno prenašati, saj so slovenske razmere drugačne od, denimo, ameriških. Možno pa je uporabiti dobre modele tako, da sledimo potrebam bodočih staršev v slovenskem prostoru.

\section{UGOTOVITVE IN ZAKLJUČKI}

Kakovostna priprava na porod in starševstvo je tista, ki vsebuje relevantna, preverjena teoretična in praktična znanja, ki jo vodi strokovno osebje, ki sloni na kakovostni komunikaciji ter ponuja mirno in varno okolje, ki spodbuja učenje. Na podlagi pregleda literature in analize primerov lahko strnemo spoznanja $\mathrm{v}$ naslednja priporočila za preoblikovanje priprav za porod in starševstvo.

- Ugotoviti je treba, kaj bodoči starši pričakujejo. Prvi pogoj za uspešno zadovoljitev potreb po izobraževanju je, da imajo šole za bodoče starše glede na potrebe posamezne skupine jasen cilj (Skubic, 2007). Današnji udeleženci priprav na porod in starševstvo so namreč pari, ki so močno motivirani za pridobivanje novih znanj, ki jim bodo $\mathrm{v}$ pomoč pri odločitvah za sooblikovanje lastne perinatalne zdravstvene obravnave. Uporabniki storitev so torej starši, ki pričakujejo objektivnost, zanesljivost, potrpežljivost, prijaznost, zaupnost, empatijo (Koželj, 2004), predvsem pa znanje (Thompson, 2009).

- Svetuje se, da se priprave na porod in starševstvo izvajajo v manjših skupinah (Walsh, 2006), da babica individualno spozna potrebe tečajnikov ter omogoča diskusijo (Ho in Holroyd, 2002; O'Meara, 1993; Leap, 2010: 28). Za zaupnost je nujno, da so udeleženci skupine stalni (Schott in Priest, 2002: 189), zaželeno pa je tudi, da tečaj vodi ista babica; še bolje je, da je to babica, ki bo žensko spremljala tudi ob in po porodu (Leap, 2010: 29). Da bi se zagotovila največja kakovost, se svetuje, da se srečanja nadaljujejo tudi v obdobju po porodu (Jaddoe, 2009), česar si želijo tudi ženske (Murphy Tighe, 2010). Treba je dodati vsebine poglobljene psihološke priprave na porod in starševstvo (o navezovanju $\mathrm{z}$ otrokom ter spremembah $\mathrm{v}$ odnosu para (Skubic, 2007), kar dokazujeta tudi (Bryan, 2000; Shapiro in Gottman, 2004, 2005).

- Poudarjajo se tudi prednosti glede kontinuitete izvajalca (Schott, 2003), vseeno pa je za največjo kakovost tečajev priprave na porod in starševstvo potrebno, da babica $\mathrm{k}$ sodelovanju povabi tudi druge strokovnjake različnih specialnosti (Leap, 2010: 30). Zato se morajo izvajalci med seboj uskladiti tako, da udeleženci ne dobivajo nasprotujočih si nasvetov in se informacije ne podvajajo (Ho in Holroyd, 2002; Schott in Priest, 2002: 11).

- Informacije morajo biti v skladu z dognanji iz najnovejših raziskav. Priprava na porod in starševstvo ne sme biti podaljšek klinične prakse (Schott in Priest, 2002: 10). Razlog je lahko, da se izvajalci bojijo v ženskah vzbuditi prevelika pričakovanja, preveliko razhajanje med pričakovanji in realnostjo pa je povezano $\mathrm{z}$ nezadovoljstvom s porodno izkušnjo. Vendar pa $\mathrm{z}$ omejevanjem informacij priprava na porod in starševstvo ni več izobraževanje, temveč indoktrinacija (Mezirow, 1983: 135).

- Izvajalce, babice in druge zdravstvene delavce (Beldon in Crozier, 2005), je nujno usposobiti za poučevanje odraslih (Skubic, 2007), ki temelji na tehnikah aktivnega učenja; npr. delo v manjših skupinah, 
voden pogovor med udeleženci (Dorsey Smith: 2) ter igranje vlog (Leap, 2010: 28). Predavanje je najmanj učinkovita metoda (Schott, 2003).

- Neupoštevanje preteklih izkušenj in znanj udeležencev povečuje tveganje, da izvajalec udeleženke in udeležence podceni, to pa vodi v pokroviteljski odnos, ki se izraža v komunikaciji (Leap, 2010: 29; Ho in Holroyd, 2002; Murphy Tighe, 2010). Poleg tega imajo zdravstveni delavci težnjo po moraliziranju, kar udeležence, ki ne ravnajo v skladu s pričakovanji, odbija in jim vzbuja krivdo (Schott in Priest, 2002:8). Jezik voditelja tečaja mora biti strokoven, a razumljiv (Schott and Priest: 2002: 49; Schott, 2003). Raba žargona in evfemizmov (npr. nelagodje namesto porodna bolečina) ni primerna, primerjave pa naj bi bile življenjske.

- Podajanje snovi naj poteka v sklopih, ki jih sestavljajo predavanja (1), ta pa naj se nadgradijo tudi s praktičnimi vajami (2) in pogovori o občutkih in mnenjih (3) (Skubic, 2007). Ženske namreč navajajo, da si želijo več možnosti, da bi preizkusile stvari, ki so jim na predavanjih teoretično predstavljene (Spiby in drugi, 1999; O'Meara, 1993; McIntosh, 1993). Le tako bi se počutile bolj kompetentne za materinsko vlogo (Fabian in drugi, 2005; Ho in Holroyd, 2002). Pripomočki, ki jih uporablja voditelj, naj bodo iz vsakodnevnega življenja, predvsem pa naj udeležencem čim več stvari pokaže sam - videoposnetki se niso izkazali za najbolj učinkovite (Schott in Priest, 2002: 82).

- Bolj kot enkratno srečanje so učinkovita večkratna zaporedna predavanja (Dorsey Smith, 1981). Priporoča se izobraževanje v več delih; ločeno za nosečnost in porod ter poporodno obdobje. Če so informacije o starševstvu podane prezgodaj, so nemalokrat neučinkovite (Walsh, 2006). Pomembno je, da je čas predavanj prilagojen (dopoldanski oziroma večerni termin). Op- timalno trajanje posameznega srečanja je ena ura (Leap, 2010: 29); od tega naj bo le prvih 20 minut tistih, ko se podaja glavnina snovi, saj je to maksimalni čas pozornosti za odraslega človeka (MacManaway, 1970, citirano po Schott in Priest, 2002: 17). Uporabna je tehnika 3×3 (Skubic, 2007). Sposobnost koncentracije nosečnic je zaradi nosečniške amnezije lahko časovno še bolj omejena (Stark, 2000; Sharp in drugi, 1993).

- Za skupinska srečanja po porodu je treba ustvariti okolje, ki je primerno tudi za novorojenčke. V Sloveniji je prva taka oblika srečevanja po porodu skupina za mamice $\mathrm{z}$ dojenčki (young mothers group), ki poteka pod vodstvom dr. Katarine Kompan Erzar s sodelavci. Ideja o skupini in srečevanju mamic $\mathrm{z}$ dojenčki po porodu je rezultat večletnih izkušenj svetovanja mladim materam, parom $\mathrm{v}$ pripravi na starševstvo in parom $\mathrm{z}$ otroki (Kompan Erzar in drugi, 2008). V nekaterih poporodnih obravnavah materam nudijo celo varstvo otroka, da se lahko ženska popolnoma osredotoči nase in na svoje potrebe (npr. v primerih poporodne depresije) (Mauthner, 1997).

- Del priprav na starševstvo naj bo usmerjeno tudi na telesno pripravo ženske na porod, ki je $\mathrm{v}$ mejah fizioloških adaptacij telesa na nosečnost. Nujno je, da je vaditelj usposobljen za vodenje nosečniške vadbe (licenca).

- Posebno pozornost je treba nameniti bodočim očetom; poleg srečanj za mešane skupine je priporočljivo organizirati tudi ločena srečanja za ženske in moške (Leap, 2010: 28), ker Swedin (1996) ugotavlja, da so potrebe očetov na prehodu v starševstvo drugačne in potrebujejo specifično obravnavo.

- Sprotna in zaključna evalvacija programa naj se izvede s samooceno in povratno informacijo udeležencev in izvajalcev. To se lahko zagotovi na neformalen način (npr. 
opazovanje, pogovor), na formalen način (evalvacijski vprašalnik) ali s pomočjo ponovnega srečanja, ki se izvede nekaj tednov po porodu. Poudarja se pomen dolgoročne evalvacije.

\section{LITERATURA IN VIRI}

Australian College of Midwives. Midwifery continuity of care. Dostopno na: http://acmi.naqtechnology.com.au/AboutUs/ACMPositionStatements/ Midwiferycontinuityofcare/tabid/809/Default.aspx $<27.10 .2010>$

Beldon, A., Crozier, S. (2005). »Health promotion in pregnancy: the role of the midwife«. The Journal of the Royal Society for the Promotion of Health, 5: 216-21.

Bick, D. (2003). »Strategies to reduce postnatal psychological morbidity: the role of midwifery services «. Disease management and health outcomes, 1: 11-20.

Bligh, D. (1998). What's the use of lectures? London: Intelect.

Bluff, R., Holloway, I. (1994). »They know best: women's perceptions of midwifery care during labour and childbirth«. Midwifery, 10: 157-64.

Brookfield, S. (1984). Understanding and Facilitating Adult Leaning. A comprehensive Analysis of Principles and Effective Practices. San Francisco: Jossey-Bass.

Callister, L.C. (2003). »The role of the nurse in childbirth: perceptions of the childbearing women $\ll$. Journal of Advanced Nurse Practitioner, 6: 288-293.

Carter, E. (1997). »Changing childbirth - challenging antenatal education? « Embase modern midwife, 2: 23 .

Davis-Floyd, R., Barclay, L., Daviss, B.A., Tritten, J. (2009). Birth models that work. Berkeley: University of California Press.

DeVries, R., Benoit, C., van Teijlingen, E., Wrede, S. (2001). Birth by design: pregnancy, maternity care and midwifery in North America and Europe. New York: Routledge.

Dick-Read, G. (1944). Childbirth without fear: the principles and practice of natural childbirth. New York: Harper.

Dorsey Smith, E. (1981). Maternity care: a guide for patient education. New York: Appleton Century Crofts.

Drglin, Z. (2003). Rojstna hiša: kulturna anatomija poroda. Ljubljana: Delta.
Drglin, Z. (2007). »Vse najboljše za rojstni dan! Ranljivost in moč žensk v sodobnih porodnih praksah.«V: Drglin Z. (ur.). Rojstna mašinerija: Sodobne obporodne vednosti in prakse na Slovenskem. Koper.

EMA (European Midwifery Association). Position papers: Statement of EMA on antenatal care. Dostopno na: http://www.europeanmidwives.eu/ ema/60Position_Papers/ANTENATAL_CARE/ $<15.8 .2011>$

Fabian, H. M., Radestad, I. J., Waldenstöm, U. (2005). »Childbirth and parenthood education classes in Sweden: women's opinion and possible outcomes «. Acta Obstet Gynecol Scand, 5: 436-43.

Flint, C., Poulengris, P. (1986). »To know your midwife Scheme report «. Midwifery, 5: 11-6.

Gale, J., Fothergill-Bourbonnais, F., Chamberlain, M. (2001). »Measuring nursing support during childbirth «. MCN, 5: 264-271.

Haines, A., Kimber, L. (2008). »Improving the birthing environment «. V: Wickham S. (ur.), Midwifery: Best Practice, Volume 5. Philadelphia.

Ho, I., Holroyd, E. (2002). »Chinese women's perceptions of the effectiveness of antenatal education in the preparation for $\operatorname{motherhood} \ll$. JAN, 1: 74-85.

Hodnett, E. D., Gates, S., Hofmeyr, G. J., Sakala, C. (2007). Continuous support for women during childbirth. Cochrane Database of Systematic Reviews, 3: 1-33.

Homer, C., Brodie, P., Leap, N. (2008). Midwifery Continuity of Care: A Practical Guide. Sidney: Churchill Livingstone/Elsevier.

Hunter, L. P. (2002). »Being With Woman: A Guiding Concept for a Care of Laboring Women«. JOGNN, 6: 650-657.

Jaddoe, V. W. (2009). »Antenatal education programmes: do they work? « The Lancet, 374: 863-864.

Kitzinger, S. (1988). »Why women need midwives«. V: Kitzinger S., The midwife challenge. London.

Kompan Erzar, K. (2003). Skrita moč družine. Ljubljana: Brat Frančišek in Frančiškanski družinski inštitut.

Kompan Erzar, K., Poljanec, A., Simonič, B., Novšak, R. (2008). »A Young Mothers'Group: A Safe Haven and Secure Base for Motherhood $\ll$. Illinois child welfare, 1: 1-2.

Koželj, R. N. (2004). Zakaj komunikacijo v zdravstvu sploh omenjamo? Dostopno na: http://home.amis. net/kozelj/nina/zdravstvo.html <1.8.2011>

Krajnc, A. (1979). »Predzakonsko in družinsko svetovanje kot andragoški pojav«. V: Svetovanje za skupno življenje. Ljubljana. 
Lamaze, F. (1958). Painless childbirth: psychoprophylactic method. London: Burke.

Leap, N. (2010). »The less we do the more we give«. V: Kirkham M., ur., The midwife-mother relationship. New York.

Leap, N., Anderson, T. (2008). »The role of pain in normal birth and the empowerment of women«. V: Downe S., ur., Normal childbirth: evidence and debate. Edinburgh.

Ličen, N. (1997). Potrebe in razvoj izobraževanja staršev. Magistrska naloga. Ljubljana: Filozofska fakulteta.

Ličen, N. (1999). Izobraževanje odraslih za življenje v družinski skupnosti. Doktorska disertacija. Ljubljana: Filozofska fakulteta.

Lundgren, I., Berg, M. (2007). »Central concepts in the midwife-woman relationship «. Scandinavian Journal of Caring Sciences, 2: 220-8.

MacArthur, C., Winter, H. R., Bick, D. E., Knowles, H., Lilford, R., Henderson, C., Lancashire, R. J., Braunholtz, D. A., Gee, H. (2002). »Effects of redesigned community postnatal care on women's health four months after birth: a cluster randomised controlled trial «. The Lancet, 2: 378-385.

Marks, M. N., Siddle, K., Warwick, C. (2003). Can we prevent postnatal depression? A randomised controlled trial to assess the impact of continuity of midwifery care on rates of postnatal depression in high risk women. Journal of Maternal Fetal and Neonatal Medicine, 13: 119-127.

Mason, G. (1995). »Governing childbirth: the wider view«. JAN, 22: 835-840.

Mauthner, N. S. (1997). »Postnatal depression: how can midwives help «. Midwifery, 4: 163-171.

McGinley, M., Turnbull, D., Fyvie, H., Johnstone, I., MacLennan, B. (1995). »Midwifery department unit at Glasgow royal maternity hospital «. British journal of midwifery, 3: 465-7.

McIntosh, J. (1993). »The experience of motherhood and the development of depression in the postnatal period «. Journal of clinical nursing, 2: 243-9.

Mezirow, J. (1983). »A critical theory of adult learning and education «. V: Tight M. (ur.), Adult learning and education. London.

Milošević, B, Prica, R. (1967). Bezbolni porođaj. Beograd: Medicinska knjiga.

Murphy Tighe, S. (2010). »An exploration of the attitudes of attenders and non-attenders towards antenatal education«. Midwifery, 3: 294-303.

Musek, J. (1995). Ljubezen, družina, vrednote. Ljubljana: Educy.

Navodila za izvajanje preventivnega zdravstvenega varstva na primarni ravni (1998). Uradni list RS 19 (807): 1253.
Nolan, M. (1994). Antenatal education: a dynamic approach. London: Bailliere Tindall, 1-4.

Nolan, M. (1997). »Antenatal education, where next?«JAN, 25: 1198-1204.

Oakley, A. (1992). »Commentary: the best research is that which breeds more «. Birth, 1: 8-9.

Oberstar, B. (2003). »Šola za starše. Ljubljana: Funkcionalno izobraževanje «. Zbornik: 44-45.

Oberstar, B. (2011). »55 let šole za starše na Ginekološki kliniki v Ljubljani«. Obzornik zdravstvene nege, 2: 152-155.

O’Meara, C. M. (1993). »An evaluation of consumer perspectives of childbirth and parenting education«. Midwifery, 9: 210-219.

Proctor, S. (1998). »What Determines Quality in $M a$ ternity Care? Comparing the Perceptions of Childbearing Women and Midwives«. Birth, 2: 85-94.

Richards, M. P. M. (1982). »The trouble with "choice' in childbirth«. Birth, 9: 253-260.

Rosen, P. (2004). »Supporting Women in Labor: Analysis of Different Types of Caregivers «. Journal of Midwifery and Women's Health, 1: 24-31.

Schott, J., Priest, J. (2002). Leading Antenatal Classes. A practical guide. Oxford: ButterworthHeinemann.

Schott, J. (2003). »Antenatal education changes and future developments «. British journal of midwifery, 10: 15-17.

Sharp, K., Brindle, P. M., Brown, M. W., Tirner, D. (1993). »Memory loss during pregnancy $\ll$. British journal of obstetrics and gynaecology, 3: 209-215.

Skočir, A. P. (2004). Midwives' and nurses' perception of their role in the prevention, detection and management of postnatal depression. MSc thesis. Aberdeen: University of Aberdeen.

Skubic, M. (2007). Izobraževanje kot del priprave na porod. Diplomsko delo. Ljubljana: Filozofska fakulteta.

SOGC (Society of Obstetricians and Gynaecologists of Canada) (1995). »Fetal health surveillance in labour«. Journal of SOGC, 9: 859-901.

Spiby, H., Henderson, B., Slade, P., Escott, D., Fraser, R. B. (1999). »Strategies for coping with labour: does prenatal education translate into practice? «JAN, 29: 388-394.

Stanek Zidarič, T., Mivšek, A. P., Skubic, M., Zakšek, T. (2011). »Kontinuirana babiška skrb: predstavitev projekta Oddelka za babištvo ZF UL in MOL. «Obzornik zdravstvene nege, 2: 141-145.

Stark, M. A. (2000). »Is it difficult to concentrate during the third trimester and postpartum? «JOGNN, 4: 378-389. 
Swedin, G. (1996). »Sodobno švedsko očetovstvo«. V: Bergstrand, G. in drugi: Prostori moškosti. Ljubljana. Thompson, A. (2009). Are antenatal classes a waste of time and cash? Dostopno na: http://women. timesonline.com.uk/tol/life_and_style/women/ families/article6439698.ece <1.8.2011>

Thorpe, J., Anderson, J. (2006). »Supporting women in labour and birth«. V: Pairman S., Pincombe J., Thorogood C. (ur.), Midwifery: preparation for practice. Sydney.

Turnbull, D., Holmes, A., Shields, N., Cheyne, H., Twaddle, S., Gilmour, J., McGinley, M., Reid, M., Johnstone, I., Greer, I., McIlwaine, G., Lunan, C. B. (1996). »Randomised controlled trial of efficacy of midwife-managed care $\ll$. The Lancet, 348: 213-218.

Twaddle, S., Liao, X. H., Fyvie, H. (1993). »An evaluation of postnatal care individualised to the needs of the woman«. Midwifery, 9: 154-60.

Wagner, M. (2007). »Evolucija k žensko osrediščeni obporodni skrbi«. V: Drglin Z. (ur.), Rojstna mašinerija: Sodobne obporodne vednosti in prakse na Slovenskem. Koper

Waldenström, U., Brown, S., McLahlan, H., Forester, D., Brennecke, S. (2000). »Does team midwife care increase satisfaction with antenatal, intrapartum and postpartum care? A randomized controlled trial«. Birth, 3: 156-167.

Walsh, D. (2006). »A new dawn for antenatal education: Taking a fresh approach «. British Journal of Midwifery, 2: 82.

Walsh, D. (2008). »Promoting normal birth: weighing the evidence $\ll$. V: Downe S. (ur.), Normal Childbirth: Evidence and debate. Edinburgh.

WHO (World Health Organization). Core documents: Philosophy/ Model of midwifery care. Dostopno na: http://www.who.int/core_dokuments/ <15.2.2011>

Williamson, S., Thomson, A. M. (1996). Women's satisfaction with antenatal care in a changing maternity service. Midwifery, 12: 198-204.

Zakšek, T., Mivšek, A. P., Skubic, M., Stanek Zidarič, T. (2011). »Zadovoljstvo babic z nudenjem kontinuirane babiške skrbi: rezultati pilotne študije«. V: Skela-Savič B. (ur.), Hvalič Touzery S. (ur.), Zurc J. (ur.), Skinder Savić K. (ur.), 4th International Scientific Conference on Research in Nursing and Health Care. Evidence-based health care-opportunities for linking health care professions, patient needs and knowledge : proceedings of lectures with peer review. Jesenice.
Zakšek, T., Mivšek, A. P. (2009). »Vloga babice pri obporodnih stiskah «. V: IVZ. Duševno zdravje in nosečnost, porod ter zgodnje starševstvo. Ljubljana. Zwelling, E. (1996). »Childbirth education the 1990's and beyond «. JOGNN, 25: 425-432.

1 Oziroma v babištvu, ki nosečnost, porod in poporodno obdobje šteje za fiziološka obdobja v življenju ženske, kjer problemi ne obstajajo, t. i. enquiry/inquiry based learning. 